\section{Implementasi Aplikasi Sistem Keuangan Desa (SISKEUDES) 2.0 Di Desa Guru Agung 1 Kecamatan Kaur Utara Kabupaten Kaur}

\section{Hadiat Trihutomo Wibowo 1), Deni Triyanto ${ }^{2)} *$, Adi Sutojo ${ }^{3)}$}

1) Program Studi Administrasi Publik, FISIP

Universitas Prof Dr Hazairin SH. Jalan

Ahmad Yani No. 1, Kota Bengkulu, Bengkulu, 38115 Indonesia.

2) Program Studi Administrasi Publik, FISIP

Universitas Prof Dr Hazairin SH. Jalan

Ahmad Yani No. 1, Kota Bengkulu, Bengkulu, 38115 Indonesia.

3) Program Studi Administrasi Publik, FISIP

Universitas Prof Dr Hazairin SH. Jalan

Ahmad Yani No. 1, Kota Bengkulu, Bengkulu, 38115 Indonesia.

* Korespondensi Penulis. E-mail: dtriyanto992@gmail.com

\section{Abstrak}

Aplikasi SISKEUDES 2.0 merupakan aplikasi yang digunakan pemerintahan desa untuk melaporkan dana desa, namun masih banyak permasalahan pada implementasi aplikasi tersebut. Penelitian ini bertujuan untuk melihat implementasi Aplikasi Siskeudes 2.0 Studi Di Desa Guru Agung 1 Kecamatan Kaur Utara Kabupaten Kaur. Penelitian ini menggunakan model implementasi Edward III. Metode Penelitian menggunakan deskriptif kualitatif dengan tujuh informan penelitian, dimana menggunakan teknik penelitian observasi dan wawancara. Hasil penelitian menjukkan bahwa implementasi aplikasi Siskeudes 2.0 di Desa Guru Agung I Kecamatan Kaur Utara Kabupaten Kaur kurang efektif, karena masih terdapat beberapa permasalah pada sumberdaya yang ada untuk mendukung implementasi aplikasi Siskudes 2.0. Selain itu juga didukung belum kurang efektifnya kinerja apartur dalam mengoprasikan apliasi Siskeudes dikarena minimnya pengetahuam dan kemampuan dibidang teknologi Informasi dan komputer. Pemerintah daerah atau pusat dapat mengevaluasi pelatihan yang selama ini diberikan kepada aparatur desa, supaya pelatihan yang selama ini diberikan dapat efektif dan dapat diaplikasikan oleh aparatur desa.

Kata kunci: Implementasi, Keuangan Desa, E-Government, Kabupaten Kaur

\section{Implementation of Village Financial} System (SISKEUDES) 2.0 Application In Guru Agung 1 Village, District Kaur Utara, Kaur Regency

\section{Abstract}

The SISKEUDES 2.0 application is an application used by village governments to report village funds, but there are still many problems in implementing the application. This study aims to see the implementation of the Siskeudes 2.0 Study Application in Guru Agung 1 Village, Kaur Utara District, Kaur Regency. This study uses the Edward III implementation model. The research method used is descriptive qualitative research with seven informants, which used observation and interview research techniques. The results show that the implementation of the Siskeudes 2.0 application in Guru Agung I Village, Kaur Utara District, Kaur Regency is not effective, because there are still several problems with the existing resources to support the implementation of the Siskudes 2.0 application. In addition, it is also supported by the ineffective performance of the apartment in operating the Siskeudes application due to the lack of knowledge and ability in the field of Information technology and computers. The regional or central government can evaluate the training that has been provided to village officials, so that the training that has been provided can be effective and can be applied by village officials.

Keywords: Implementation, Village Finance, E-Government, Kaur Regency 


\section{A. PENDAHULUAN}

Undang-Undang Nomor 6 Tahun 2014 tentang Desa, desa diberikan kesempatan yang besar untuk mengurus tata pemerintahannya sendiri serta pelaksanaan pembangunan untuk meningkatkan kesejahteraan dan kualitas hidup masyarakat desa. Selain itu pemerintah desa diharapkan untuk lebih mandiri dalam mengelola pemerintahan dan berbagai sumber daya alam yang dimiliki, termasuk di dalamnya pengelolaan keuangan dan kekayaan milik desa. Begitu besar peran yang diterima oleh desa, tentunya disertai dengan tanggung jawab yang besar pula. Oleh karena itu pemerintah desa harus bisa menerapkan prinsip transparansi dan akuntabilitas'.

Sebelum aplikasi Sistem Keuangan Desa (SISKEUDES) diluncurkan, sebagian besar desa membuat anggaran, pembukuan, dan laporan keuangan menggunakan Microsoft Excel atau aplikasi lain yang formatnya tidak standar. Hal ini menyulitkan pemerintah kabupaten/kota dalam mengevaluasi APBDes dan laporan keuangan desa. Selain itu, ada ratusan desa yang menggunakan aplikasi yang dibeli dari pengembang swasta, yang tidak dapat diperbarui untuk memenuhi standarstandar regulasi.

SISKEUDES dikembangkan oleh BPKP dengan pendekatan pemerintah daerah, sehingga memudahkan dalam proses kompilasi laporan keuangan seluruh desa menjadi lampiran LKPD sesuai dengan peraturan perudangundangan. Pemerintah daerah memiliki peran penting dalam pembinaan implementasinya melalui pengaturanpengaturan yang sesuai dengan regulasi. aplikasi SISKEUDES telah mengakomodir seluruh regulasi terkait dengan keuangan desa, dirancang secara terintegrasi, user friendly, dan desktop application serta memiliki sistem pengendalian intern yang melekat dan efektif dalam menghasilkan informasi keuangan. Hal ini tentunya akan memberikan rasa nyaman bagi pengelola keuangan di desa dalam mewujudkan akuntabilitas pengelolaan keuangan desa (Firdausy, Suryana, Nugroho, \& Suhartoko, 2019).

Aplikasi Sistem Keuangan Desa (Siskeudes) yang sebelumnya dikenal dengan nama SIMDA Desa merupakan aplikasi sederhana yang dikembangkan Badan Pengawasan Keuangan dan Pembangunan (BPKP) bersama Ditjen Bina Pemerintahan Desa Kementerian Dalam Negeri. Aplikasi ini dikembangkan dalam rangka meningkatkan kualitas tata kelola keuangan desa. Fitur-fitur yang ada dalam aplikasi Siskeudes dibuat sederhana dan user friendly sehingga memudahkan pengguna dalam mengoperasikan aplikasi Siskeudes (Puspasari \& Purnama, 2018).

Menurut Undang-Undang No. 6 Tahun 2014 keuangan desa merupakan semua hak dan kewajiban desa yang dapat dinilai dengan uang serta segala sesuatu berupa uang dan barang yang berhubungan dengan pelaksanaan hak dan kewajiban desa. Dalam hal keuangan desa, pemerintah desa wajib untuk menyusun laporan Realisasi Pelaksanaan APBDes dan Laporan Pertanggung jawaban Realisasi Pelaksanaan APBDes. Laporan ini dihasilkan dari suatu siklus pengelolaan keuangan desa, yang dimulai dari 
Vol.2 No.2 Desember 2020

tahapan perencanaan dan

penganggaran, pelaksanaan dan penatausahaan, hingga pelaporan dan pertanggungjawaban pengelolaan keuangan desa. (Jamaluddin, Sumaryana, Rusli, \& Buchari, 2018)

Perwujudan akuntabilitas dan menumbuhkan kepercayaan publik terhadap kinerja keuangan pemerintah, saat ini telah menjadi isu penting dalam pengelolaan keuangan Negara. Pengelolaan keuangan desa juga semakin dituntut untuk dapat mewujudkan akuntabilitas, namun pada kenyataannya akuntabilitas pengelolaan keuangan desa masih dalam kategori rendah. Rendahnya akuntabilitas dapat mengakibatkan kegagalan administrasi, miskin keputusan politik, dan tingginya tindakan korupsi.

Pengawalan Keuangan Desa yang dilakukan oleh BPKP sendiri bertujuan untuk memastikan seluruh ketentuan dan kebijakan dalam mengimplementasikan UU Desa khususnya keuangan desa dapat dilaksanakan dengan baik untuk seluruh tingkatan pemerintahan baik tingkat Pemerintah Pusat (Kementerian/ Lembaga), Pemerintah Provinsi, Pemerintah Kabupaten/Kota, Pemerintah Kecamatan dan Pemerintah Desa sesuai dengan perannya masingmasing. Khusus untuk tingkat desa, pemerintah desa dapat melaksanakan siklus pengelolaan keuangan desa dengan baik mulai dari perencanaan, pelaksanaan, penatausahaan, pelaporan, pertanggung jawaban dan pengawasan. Jika berhasil dilaksanakan dengan baik maka pengawalan desa akan mencapai tujuan yang diharapkan yaitu Good
Village Governance (Pratiwi \& Pravasanti, 2020).

Pengembangan Aplikasi Sistem Tata Kelola Keuangan Desa telah dipersiapkan sejak awal dalam rangka mengantisipasi penerapan UU Nomor 6 Tahun 2014 tentang Desa. Persiapan ini selaras dengan adanya perhatian yang lebih dari Komisi XI Dewan Perwakilan Rakyat RI maupun Komisi Pemberantasan Korupsi. Launching aplikasi yang telah dilaksanakan pada tanggal 13 Juli 2015 merupakan jawaban atas pertanyaan pada Rapat Dengar Pendapat (RDP) Komisi XI tanggal 30 Maret 2015, yang menanyakan kepastian waktu penyelesaian aplikasi yang dibangun oleh BPKP, serta memenuhi rekomendasi KPK-RI untuk menyusun sistem keuangan desa bersama dengan Kementerian Dalam Negeri (Malahika, Karamoy, \& Pusung, 2018).

Kajian tentang Pengelolaan Keuangan Desa oleh KPK memperoleh hasil bahwa terdapat potensi korupsi dalam pengelolaan keuangan desa yang dapat dilihat dari masalah tata laksana yaitu kerangka waktu siklus pengelolaan anggaran desa sulit dipatuhi oleh desa, APBDesa yang disusun tidak sepenuhnya menggambarkan kebutuhan yang diperlukan desa, transparansi rencana penggunaan dan pertanggungjawaban APBDesa masih rendah dan laporan pertanggungjawaban yang dibuat desa belum sepenuhnya mengikuti standar dan rawan manipulasi (Munti, 2017). Fenomena yang ada di Desa Guru Agung I pada penerapan SISKUDES terdapat permasalah pada sumberdaya manusia yang kurang memumpuni, sehingga 
Vol.2 No.2 Desember 2020

implementasi aplikasi SISKEUDES

kurang efektif.

Petingnya pemahaman aparatur pemerintahan Desa Guru Agung 1 dalam mengimplementasikan Aplikasi Siskeudes 2.0 sangat peting, karena apartur pemerintahan desa sebagai pelaksana aplikasi tersebut, oleh karena itu aparut pemerintahan desa dituntut melek teknologi informasi guna menyukseskan penerpanan aplikasi siskeudes di Kabupaten Kaur Provinsi Bengkulu. Oleh karena itu penelitian ini berfokus pada implementasi SISKEUDES di Desa Guru Agung I, dengan menggunakan model implementasi Edward III untuk melihat bagaimana komunikasi, sumberdaya, disposisi, struktur birokrasi pada penerapan aplikasi SISKEUDES 2.0.

\section{B. TEORI (Literature Review)}

Adapun beberapa hasil penelitian terdahulu yang relevan. Pertama, Analisis Persepsi Aparatur desa terhadap penerimaan dan penggunaan aplikasi sistem keuangan desa (SISKEUDES) di kabupaten ketapang (Kurnia, 2019). Hasil penelitian ini menunjukan bahwa persepsi penggunaan dan minat perilaku menggunakan teknologi terbukti tidak mempengaruhi penggunaan secara nyata. Pengalaman terbukti tidak mempengaruhi persepsi kegunaan tetapi pengalaman terbukti memiliki pengaruh terhadap persepsi kemudahan dalam menggunakan teknologi dalam sistem keuangan desa (SISKEUDES).

Kedua, Kualitas Pelayanan Publik di Kantor Perwakilan Pemerintah Daerah Kabupaten Tolitoli di Kota Palu
(Yuningsih, 2016). Penelitian ini menggunakan metode penelitian deskriftif kualitatif dengan Teknik pengumpula data melalui observasi, wawancara dan dokumentasi. Hasil penelitian ini menunjukan bahwa pelayanan pegawai pada Kantor Perwakilan Pemerintah Daerah Kabupaten Tolitoli dilihat dari dimensi empathy belum sepenuhnya berjalan dengan baik. Hal ini terlihat dari belum adanya hubungan yang baik anatara petugas/aparatur dengan tamu/ pengunjung pengguna jasa penginapan.

Ketiga, E-Government dan Aplikasinya di Lingkungan Pemerintah Daerah (Studi Kasus Kualitas Informasi Website Kabupaten Bengkalis Propinsi Riau) (Damanik \& Purwaningsih, 2017). Penelitian ini menggunakan pendekatan kualitatif dengan metode studi kasus. Adapun hasil penelitian yang diperoleh bahwa informasi yang tersedia di website Pemkab Bengkalis sudah memenuhi kualitas informasi yang baik, meskipun terdapat beberapa kekurangan seperti adanya tautan (link) ke halaman kosong, sebagian penanggalan informasi yang belum tercantum, dan belum adanya jaminan kualitas jaringan untuk memastikan ketersediaan informasi.

Keempat, Analisis Peran Aplikasi Sistem Keuangan Desa (Siskeudes) Dalam Meningkatkan Kualitas Akuntabilitas Keuangan Desa Di Tinjau Dari Perspektif Ekonomi Islam Desa Bogorejo, Kecamatan Gedong Tataan, Kabupaten Pesawaran (Ridwan, 2019). Penelitian ini menggunakan metode penelitian deskriptif dengan analisis kualitatif dan tehnik analisis data yang akan digunakan dalam penelitian ini 
adalah kualitatif dengan langkahlangkah reduksi data, displya data, verifikasi data atau penarikan kesimpulan. Hasil penelitian ini menunjukan (1) untuk pengelolaan aplikasi SISKEUDES di Desa Bogorejo sudah terstruktur dengan baik dan memenuhi standar penerapan serta melakukan proses pertanggungjawaban yang relevan, sehingga semua proses pengelolaan sudah baik. (2) aplikasi sistem keuangan desa (SISKEUDES) sangat membawa perubahan yang baik di Desa Bogorejo, karena mempermudah dalam pelaporan pertanggungjawaban, menghasilkan laporan keuangan yang akurat, relevan dan mampu menyajikan laporan keuangan dengan wajar sesuai dengan Peraturan Pemerintah No. 24 Tahun 2005, sehingga dengan penerapan aplikasi sistem keuangan desa mampu berperan dalam meningkatkan kualitas akuntabilitas keuangan desa dalam rangka mewujudkan tata kelola desa yang baik.

Kelima, endang (Endang \& Hayati, 2020) dengan judul penelitian "Implementasi Aplikasi Sistem Keuangan Desa (Siskeudes). Di Desa Bogorejo, Kecamatan Gedong Tataan, Kabupaten Pesawaran". Hasil penelitian menunjukkan bahwa implementasi aplikasi sistem keuangan desa dari segi komunikasi, sumber daya, disposisi dan struktur birokrasi sudah berjalan dengan cukup baik. Pelaksanaan aplikasi sistem keuangan desa menjadi lebih terpola dan terstruktur dengan baik dikarenakan setiap dana yang dikeluarkan harus ditandai dengan surat permintaan pembayaran, pada pelaksanaan aplikasi sistem keuangan desa juga masih ditemukan adanya kelemahan pada indikator komunikasi yang ditransimiskan oleh BPKP dinilai kurang maksimal oleh para pelaksana program, serta kelemahaan pada aplikasi yang mudah terkena virus dan aplikasi ini belum online sehingga belum terkoneksi langsung dengan pemerintah kabupaten.

Berdasarkan hasil penelitian terdahulu bahwa dalam pelaksanaan aplikasi SISKEUDES diperlukan pengetahuan dan pengalaman apartur pemerintahan desa dalam pengunaan teknologi informasi oleh sebab itu perlu adanya pelatihan atau workshop secara berkelanjutan. Selain itu kelemahan yang ada di desa-desa kususnya desa yang berada jauh dari Kota terkendala oleh prangkat dan jaringan internet yang memadai.

\section{METODE}

Berdasarkan hasil penelitian dengan menggunakan metode kualitatif dengan pendekatan deskriptif (Creswell, 2014) Fokus penelitiannya tentang peranan aparatur pemerintahan Desa dalam implementasikan Aplikasi SISKEUDES 2.0 Di Desa Guru Agung 1 Kecamatan Kaur Utara Kabupaten Kaur. Aspek yang dilihat bagaimana implementasi Aplikasi SISKEUDES 2.0 yaitu menggunakan teori Edward III yaitu komunikasi, sumberdaya, disposisi dan struktur birokrasi. Adapun lasanan dalam memilih teori ini menurut peneliti bahwa teori edward III ini yang sangat relavan sebagai alat analisis. Dengan menggunakan teknik penentuan informan purposive sampling, dengan sengaja menentukan atas dasar pertimbangan tertu yaitu terdiri dari 
Kepala Desa, Sekertaris Desa, Kaur Keuangan, 2 Prankat Desa, 1 BPD dan 1 Tokoh Mayarakat.

Instrumen utama penelitian ini, yaitu peneliti sendiri dengan menggunakan pedoman wawancara yang bisa dikembangkan sesuai dengan situasi di lapangan. Selain itu peneliti juga melakukan studi dokumentasi atas hal-hal yang berkaitan dengan masalah yang diteliti. Teknik analisis data penelitian ini menggunakan model Miles dan Hubermen, yaitu: data display, data reduction dan conclusion drawing (Muhadjir, 2012) , dengan memaparkan data-data yang diperoleh dari lapangan, kemudian meredukasi data-data inti dengan cara merangkum dan langkah selanjutnya membuat kesimpulan.

\section{HASIL DAN PEMBAHASAN}

Implementasi aplikasi Siskeudes 2.0 di Desa Guru Agung I Kecamatan Kaur Utara Kabupaten Kaur kurang efektif dikarenakan berdasarkan analisis implementasi menggunakan model edward III bahwa indikator komunikasi masih cukup efektif antara pelaksana program SISKEUDES 2.0 yaitu kepala desa, sekretaris desa, bendahara dan BPD. Untuk indikator sumberdaya masih terdapat permasalahan pada sarana dan pra sarana yang masih kurang maksimal yang ada di Desa Guru Agung satu dalam implementasikan aplikasi SISKEUDES 2.0. Hal ini merupakan salah satu kelemahan yang ada di desa-desa yang ada di Kabupaten Kaur yang saat ini masih banyaknya desa-desa yang minimnya sarana dan prasaran pendukung untuk implementasikan aplikasi SISKEUDES 2.0.

\section{Komunikasi dalam implementasi Aplikasi Siskeudes 2.0}

Komunikasi merupakan faktor terpenting implementasi aplikasi sikeudes 2.0 dikarena pihak Desa harus terus berkoordinasi (BPD) dengan Badan Permusyawaratan Desa baik dalam penetapan maupun perubahan APBDes. Seperti yang dikatakan oleh Kepala Desa Guru Agung 1 mengatakan bahwa:

"sejak aplikasi Siskeudes diimplementasikan dalam pengelolaan keuangan desa harus berkoordinasi dengan pihak BPD dalam mentapkan dan perubahan APBDes selama 3-5 kali dalam setahun. Adapun pihak-pihak yang hadir dalam menetapkan APBDes yaitu masyarakat desa dan aparatur Desa Guru Agung I, jadi komunikasi dalam pengelolaan keuangan desa terjalin dengan baik dan jelas dalam pengelolaannya, saling transparansi dalam pengelolaannya". (3/4/2019)

Hal ini kemudian diperkuat oleh salah satu tokoh masyarakat Desa Guru Agung 1 bahwa:

"saya selaku masyarakat merasakan bahwa komunikasi yang terjalin oleh pemerintah Desa Guru Agung I dengan Badan Pemusyawaratan Desa (BPD) sangat baik dalam pengelolaan keuangan desa, pihak pemerintahan desa juga melibatkan dalam menetapkan APBDes". (15/4/2019)

Berdasarkan hasil wawancara dan observasi dapat disimpulakan bahwa komunikasi yang terjalin cukup baik antara pemerintah desa, DPD dan masyarakat baik dalam menetapakan APBDes ataupun dalam pembangunanpembangunan Desa Guru Agung I. 
$\begin{array}{ll} & \text { Petingnya komunikasi yang baik } \\ \text { dalam implementasi aplikasi }\end{array}$ SISKEUDES 2.0, komunikasi yang terbentuk antara kaur keuangan, sekertaris desa dan kepala desa juga harus baik karena pada saat mengimplementasikan SISKEUDES 2.0 banyak unsur yang harus diisi dalam aplikasi tersebut, ketika komunikasi tidak baik maka akan menjadi kendala pada saat pengisisian aplikasi SISKEUDES 2.0. Oleh sebab itu, pada model implementasi edward III ini komunikasi menjadi salah satu indikator penting sukses tidaknya dalam implementasi suatu kebijakan atau program pemerintah.

\section{Sumberdaya dalam implementasi Aplikasi Siskeudes 2.0}

Sumberdaya merupakan faktor penting dalam mengimplementasikan aplikasi Siskeudes 2.0, dibutuhan sumberdaya manusia yang mempuni, sarana dan prasaran yang mendukung. Masih banyaknya sumberdaya manusia yang kurang berkompeten di Desa Guru Agung I dan minimnya sarana prasarana mengakibatkan kurang maksimalnya implementasi Aplikasi Siskeudes 2.0. Sumberdaya manusia merupakan faktor penggerak dalam melaksanakan suatu kegiatan kusunya pengoprasian aplikasi Siskeudes 2.0., seperti yang dikatakan oleh Bendahara Desa Guru Agung I Kecamatan Kaur Utara Kabupaten Kaur bahwa :

"Selama ini belum adanya fasilitas yang diberikan oleh pemerintah daerah untuk mendukung impelementasi aplikasi Siskeudes 2.0, selama ini kami menggunakan laptop pribadi dan komputer satu-satumya yang biasaya kami gunakan untuk pelayanan masyarakat di Desa Guru Agung I" (12/4/2019)

Selain itu juga diperkuat pendapat dari sekretaris Desa Guru Agung I yaitu sebagai berikut :

"Mengenai sumberdaya apartur dalam ngengoperasinya saya masih di bantu dari pendamping desa yang paham dan ahli dalam pengoperasian aplikasi Sistem Keuangan desa di karenakan agar dalam pencairan tidak tertinggal dari desa desa lainnya". (13/4/2019)

Berdasarkan hasil wawancara diatas bahwa masih minimnya pengetahuan sumberdaya manusia dan sarana dan prasarana untuk mendukung implementasi aplikasi Siskeudes, melihat hal ini pemerintah juga tidak tinggal diam karena menurunkan pendamping desa guna memantau pembangunan desa, baik pembangunan fisik maupun non fisik (Triyanto, 2018)

Sarana dan pra sarana yang masih kurang maksimal yang ada di Desa Guru Agung satu dalam implementasikan aplikasi SISKEUDES 2.0, ini merupakan salah satu kelemahan yang ada di desadesa yang ada di Kabupaten Kaur yang saat ini masih banyaknya desa-desa yang minimnya sarana dan prasaran pendukung untuk implementasikan aplikasi SISKEUDES 2.0. oleh sebab itu perlunya pemerintah desa melakukan komunikasi ke Dinas Pemberdayaan Masyarakat dan Desa (DPMD) yang ada di Kabupaten Kaur untuk dapat mengevaluasi permasalahan yang muncul supaya dapat dilakukan tindakan untuk memperbaiki sarana dan prasaran. 
Penerapan elektronik government tidaklah mudah, apabila pemerintah inggin merapakan pemerintah berbasis digital diperlukannya kesiapan diseluruh stakeholders terkait (Triyanto \& Efendi, 2019). Kususnya pada pemerintah daerah yang kurangnya akses jaringan dan minimnya sarana dan prasarana untuk menerapkan pemerintah berbasih digital. Oleh karena itu petingnya kolaborasi aantara pemerintah pusat, provinsi, kabupaten/kota (Harmiati, Alexsander, Triyanto, Maya, \& Riastuti, 2020)

Selain itu kualitas sumberdaya manusia yang ada di Desa Guru Agung I juga masih rendah, mungkin saja ini juga terjadi di Desa-desa yang ada di Kabupeten Kaur yang masih memiliki kualitas sumberdaya manusia yang rendah seperti di desa-desa pulau jawa yang secara kualitas memiliki SDM yang baik. Kualitas sumberdaya manusia yang ada di Pemerintahan Desa Guru Agung I ini dikarena minimnya sarjana yang mau bergabung di Desa, sebenarnya sudah mulai banyak yang kuliah dan lulus sarjana, hanya saja masih banyaknya yang tidak mau pulang ke Desa dikarena mereka berfikir bahwa ketika mereka pulang ke Desa Guru Agung I meraka tidak mendapat pekerjaan yang lebih baik dibandingkan tetap tinggal di Kota.

Hal ini yang mengakibatkan minimnya sumerdaya manusia yang berkualitas yang ada di Pemerintahan Desa Guru Agung I, oleh sebab itu perlunya DPMD Kabupaten Kaur dapat mengevaluasi ke Provinsi dan Provinsi dapat mengkomunikasikan ke Pusat, supaya adanya kebijakan-kebijakan yang mungkin kedepat mensyaratkan staf pemerintahan desa memiliki pendidikan minimal sarjana bidang ekonomi, administrasi publik dan teknogi informasi, sehingga kinerjanya juga dapat maksimal seperti desa-desa yang ada di Pulau Jawa.

Permasalah sumberdaya manusia yang ada di desa-desa di Provinsi Bengkulu ini merupakan permasalah yang sudah lama, namun sampai saat ini belum adanya tindakan dari pemerintah pusat atau daerah untuk memberikan trobosan-trobosan untuk menanganinya, kami rasa bahwa permasalahan ini tidak hanya terjadi di Provinsi Bengkulu saja melainkan pada desa-desa di daerah Indonesia Timur.

\section{Disposisi dalam implementasi} Aplikasi Siskeudes 2.0

Suatu kebijakan atau program akan berhasil dengan baik dalam implementasinya apabila didukung oleh aparat pelaksana, perilaku aparat pelaksana yang positif dan sesuai dengan prosedur dalam mengimplementasikan, penempatan atau penyusunan aparat pelaksana dilakukan berdasarkan prinsip the right man in the right place dan motivasi aparat pelaksana dalam bekerja sangat tinggi serta sikap masyarakat.

Demikian pula dengan implementasi aplikasi Sikeudes 2.0 akan berhasil dengan baik dalam implementasinya jika didukung oleh aparat pelaksana, perilaku aparat pelaksana yang positif dan sesuai dengan prosedur dalam mengimplementasikan kebijakan, penempatan atau penyusunan aparat pelaksana dilakukan berdasarkan prinsip the right man in the right place dan motivasi aparat pelaksana dalam 
bekerja sangat tinggi serta sikap masyarakat (Harmiati, Mulyadi, Suri, \& Triyanto, 2019). Hasil penelitian menunjukkan bahwa faktor disposisi dalam implementasi aplikasi siskeudes 2.0 di Desa Guru Agung 2.0 belum efektif, karena kurang efektifnya kinerja apartur dalam mengoprasikan apliasi Siskeudes dikarena minimnya pengetahuam dan kemampuan dibidang teknologi Informasi dan komputer.

Sikap pelaksana aplikasi SISKEUDES 2.0 di Desa Guru Agung I ini kurang efektif karena minimnya pengetahuan pelaksana aplikasi SISKEUDES 2.0, apara implementor masih melakukan dikresi dengan melakukan menyuruh orang lain untuk membuat laporan APBdes dengan mengunakan aplikasi SISKEUDES 2.0, sehingga ini merupakan hambatan pada pelaksanaan aplikasi tersebut.

Oleh sebab itu kualitas implementor sangatlah berdampak pada pelaksanaan aplikasi SISKEUDES 2.0 di Desa Guru Agung I karena sampai saat ini indikator disposisi ini masih kurang efektif, dikarena Kepala Desa kurang aktif dalam meningkatkan semangat dan motivasi pelaksana, mungkin dengan membuat trobosan berupa insetif bagi pengelola SISKEUDES 2.0 di Desa Guru Agung I, secara tidak langsung dampat memberikan dampak yang baik kepada tingkat motivasi pengelola SISKEUDES 2.0 sebagai pelaksana.

Insentif yang diberikan kepala desa yang menarik dapat menumbuhkan etos kerja pelaksana aplikasi SISKEUDES 2.0, apabila para pelaksana sudah memiliki etos kerja otomatis mereka akan giat belajar aplikasi tersebut supaya meraka dapat melaksanakan aplikasi SIKEUDES 2.0 sesuai denga standar oprasional prosedur yang berlaku, dengan demikian para pelaksana tidak lagi menyuruh orang lain untuk mengerjakan tugasnya sebagai pelaksana aplikasi tersebut.

Selain itu, hasil observasi juga masih kurang maksimalnya pelatihan yang diberikan oleh Dinas PMD Kabupaten Kota atau Provinsi pada saat ini, workshop yang diberikan masih kaku untuk diterima mereka yang memiliki usia yang tidak muda lagi, selin itu juga pendidikan mereka masih Sekolah Menengah Atas atau Sekolah Menengah Kejuruan dan pada masanya teknologi informasi belum berkembang seperti saat ini, sehingga mereka sedikit lambat untuk menerima materi-materi yang berat dan membosankan. Peran para stakeholders terkait ini sangat penting untuk dapat mengevaluasi teknik pelatihan yang selama ini masih dianggap kaku, untuk dapat diubah lebih responsif dan mudah diterima oleh para peserta workshop yang beraneka ragam latarbelakang pendidikan dan usia.

\section{Struktur Birokrasi dalam implementasi Aplikasi Siskeudes 2.0}

Struktur birokrasi dalam implementasi kebijakan memegang peranan yang sangat penting, karena berkaitan dengan prosedur, sistem kerja, pembagian kerja, wewenang dan koordinasi antar instansi. Tidak bedanya dengan implementasi aplikasi Siskeudes 2.0 harus sesuai dengan prosedur, dengan sistem kerja yang baik, pembagian kerja, wewenang dan 
Vol.2 No.2 Desember 2020

koordinasi antar instansi harus dilakukan dengan baik sesuai dengan ketentuan yang berlaku. Memperhatikan hasil penelitian menunjukkan bahwa faktor struktur birokrasi dalam aplikasi Siskeudes 2.0 di Desa Guru Agung I cukup efektif. Pentingnya kolaborasi antar stakeholders untuk meningkatkan implementasi aplikasi Sikeudes $2.0 \mathrm{di}$ Desa Guru Agung I Kecamatan Kaur Utara Kabupaten Kaur. Kolaborasi merupakan faktor penting dalam menyukseskan program pemerintah (Harmiati et al., 2020).

Struktur birokrasi dalam penerapan SISKEUDES 2.0 masih kurang efektif, dikarena pengelola aplikai SISKEUDES ini yaitu bendahara Desa, karena hal tersebut terkadang Kepala Desa masih tergolong tidak pedula bagaimana prosesnya, karena itu sudah menjadi tugas pokok dan fungsi Bendahara, seharusnya apabila struktur birokrasi itu baik, maka sebagai pimpinan lebih proaktif terhadap kelemahan-kelembahan yang ada di setiap devisi, sehingga dapat membuat inovasi supaya tujuan organisasi tercapai. Selanjutnya, kelemahan yang ada ini sebenarnya sudah terbaca oleh Dinas pemberdayaan Masyarakat dan Desa, dengan memeberikan pelatihan namun kurang efektif, ketika pemerintah desa ingin mencari prangkat desa penganti juga bermasalah pada persedian sumberdaya manusia yang berkualitas yang ada Di Desa Guru Agung I Kecamatan Kaur Utara Kabupaten Kaur. Apabila DPMD inggin mencarikan sumberdaya manusia yang berkualitas dari daerah lain itu menyalahi kewenangannya, karena itu

merupakan kewenangan desa masingmasih.

Fenomena yang ada di desa-desa Kabupaten Kaur saat ini masih menggunakan sumberdaya manusia yang tersedia di desanya tidak pernah mengrekrut dari daerah lain, karena memang aturan tentang standar rekrutmen perangkat desa ini belum diatur oleh pusat, sehingga daerah apalagi desa tidak dapat sembarangan melakukan perekrutan dengan cara terbuka, sampai saat ini perekrutan dengan cara terbuka kusus desanya masing-masing. Ini merupakan salah satu dasar untuk kemeterian desa supaya dapat membuat regulasi untuk rekrutan prangkat dengan dengan sistem terbuka, mungkin dapat dengan cara perekrutan pegawai pemerintah denagan perjanjian kerja sehingga kedepan pelamar akan lebih banyak dan seleksi akan lebih ketat dan dapat memperoleh prangkat desa yang memiliki kompetensi yang baik. Selain itu juga dapat menjadi motivasi masyarakat desa yang tidak ada niat kuliah dapat kuliah dan yang sudah lulus sarjana dapat pulang desa untuk membangun desa, dengan demikian seluruh desa di Indonesia akan dapat lebih maju baik secara ekonomi, sumberdaya dan pembangunan fisik.

\section{E. SIMPULAN DAN SARAN \\ 1. Kesimpulan}

Berdasarkan hasil penelitian dan pembahasan, maka peneliti dapat menarik kesimpulan bahwa implementasi aplikasi Siskeudes $2.0 \mathrm{di}$ Desa Guru Agung I Kecamatan Kaur Utara Kabupaten Kaur kurang efektif, karena berdasarkan analisis 
implementasi menggunakan model edward III bahwa indikator komunikasi masih cukup efektif anatara pelaksana program SISKEUDES 2.0 yaitu kepala desa, sekretaris desa, bendahara dan BPD, kemudian untuk indikator sumberdaya yaitu masih terdapat permasalahan pada Sarana dan pra sarana yang masih kurang maksimal yang ada di Desa Guru Agung satu dalam mengimplementasikan aplikasi SISKEUDES 2.0, ini merupakan salah satu kelemahan yang ada di desa-desa yang ada di Kabupaten Kaur yang saat ini masih banyaknya desa-desa yang minimnya sarana dan prasaran pendukung untuk implementasikan aplikasi SISKEUDES 2.0. oleh sebab itu perlunya pemerintah desa melakukan komunikasi ke Dinas Pemberdayaan Masyarakat dan Desa (DPMD) yang ada di Kabupaten Kaur untuk dapat mengevaluasi permasalahan yang muncul supaya dapat dilakukan tindakan-tindakan untuk memperbaiki sarana dan prasaran.

Selain itu kualitas sumberdaya manusia yang ada di Desa Guru Agung I juga masih rendah, mungkin saja ini juga terjadi di Desa-desa yang ada di Kabupeten Kaur yang masih memiliki kualitas sumberdaya manusia yang rendah seperti di desa-desa pulau jawa yang secara kualitas memiliki SDM yang baik. Kualitas sumberdaya manusia yang ada di Pemerintahan Desa Guru Agung I ini dikarena minimnya sarjana yang mau bergabung di Desa, sebenarnya sudah mulai banyak yang kuliah dan lulus sarjana, hanya saja masih banyaknya yang tidak mau pulang ke Desa dikarena mereka berfikir bahwa ketika mereka pulang ke
Desa Guru Agung I meraka tidak mendapat pekerjaan yang lebih baik dibandingkan tetap tinggal di Kota. Permasalah sumberdaya manusia yang ada di desa-desa di Provinsi Bengkulu ini merupakan permasalah yang sudah lama, namun sampai saat ini belum adanya tindakan dari pemerintah pusat atau daerah untuk memberikan trobosan-trobosan untuk menanganinya, kami rasa bahwa permasalahan ini tidak hanya terjadi di Provinsi Bengkulu saja melainkan pada desa-desa di daerah Indonesia Timur.

Indikator disposisi menunjukan kurang efektif, karena kurang efektifnya kinerja apartur dalam mengoprasikan apliasi Siskeudes dikarena minimnya pengetahuam dan kemampuan dibidang teknologi Informasi dan komputer. Sikap pelaksana aplikasi SISKEUDES 2.0 di Desa Guru Agung I ini kurang efektif karena minimnya pengetahuan pelaksana aplikasi SISKEUDES 2.0, apara implementor masih melakukan dikresi dengan melakukan menyuruh orang lain untuk membuat laporan APBdes dengan mengunakan aplikasi SISKEUDES 2.0, sehingga ini merupakan hambatan pada pelaksanaan aplikasi tersebut.

Oleh sebab itu kualitas implementor sangatlah berdampak pada pelaksanaan aplikasi SISKEUDES 2.0 di Desa Guru Agung I karena sampai saat ini indikator disposisi ini masih kurang efektif, dikarena Kepala Desa kurang aktif dalam meningkatkan semangat dan motivasi pelaksana, mungkin dengan membuat trobosan berupa insetif/riwerd bagi pengelola SISKEUDES 2.0 di Desa Guru Agung I, secara tidak langsung dampat 
memberikan dampak yang baik kepada tingkat motivasi pengelola SISKEUDES 2.0 sebagai pelaksana. Namun, selain itu hasil observasi juga masih kurang maksimalnya pelatihan yang diberikan oleh Dinas PMD Kabupaten Kota atau Provinsi pada saat ini, workshop yang diberikan masih kaku untuk diterima mereka yang memiliki usia yang tidak muda lagi, selin itu juga pendidikan mereka masih Sekolah Menengah Atas atau Sekolah Menengah Kejuruan dan pada masanya teknologi informasi belum berkembang seperti saat ini, sehingga mereka sedikit lambat untuk menerima materi-materi yang berat dan membosankan. Peran para stakeholders terkait ini sangat penting untuk dapat mengevaluasi teknik pelatihan yang selama ini masih dianggap kaku, untuk dapat dirubah lebih lues dan mudah diterima oleh para peserta workshop yang beraneka ragam latarbelakang pendidikan dan usia.

Indikator Struktur Birokrasi menunjukan kurang efektif, dikarena pengelola aplikai SISKEUDES ini yaitu bendahara Desa, karena hal tersebut terkadang Kepala Desa masih tergolong tidak pedula bagaimana prosesnya, karena itu sudah menjadi tugas pokok dan fungsi Bendahara, seharusnya apabila struktur birokrasi itu baik, maka sebagai pimpinan lebih proaktif terhadap kelemahan-kelembahan yang ada di setiap devisi, sehingga dapat membuat trobosan-trobosan supaya tujuan organisasi tercapai. Selain itu, kelemahan yang ada ini sebenarnya sudah terbaca oleh Dinas pemberdayaan Masyarakat dan Desa, dengan memeberikan pelatihan namun kurang efektif, ketika pemerintah desa ingin mencari prangkat desa penganti juga bermasalah pada persedian sumberdaya manusia yang berkualitas yang ada Di Desa Guru Agung I Kecamatan Kaur Utara Kabupaten Kaur. Apabila DPMD inggin mencarikan sumberdaya manusia yang berkualitas dari daerah lain itu menyalahi kewenangannya, karena itu merupakan kewenangan desa masing-masih.

Fenomena yang ada di desa-desa Kabupaten Kaur saat ini masih menggunakan sumberdaya manusia yang tersedia di desanya tidak pernah mengrekrut dari daerah lain, karena memang aturan tentang standar rekrutmen perangkat desa ini belum diatur oleh pusat, sehingga daerah apalagi desa tidak dapat sembarangan melakukan perekrutan dengan cara terbuka, sampai saat ini perekrutan dengan cara terbuka kusus desanya masing-masing. Ini merupakan salah satu dasar untuk kemeterian desa supaya dapat membuat regulasi untuk rekrutan prangkat dengan dengan sistem terbuka, mungkin dapat dengan cara perekrutan pegawai pemerintah denagan perjanjian kerja sehingga kedepan pelamar akan lebih banyak dan seleksi akan lebih ketat dan dapat memperoleh prangkat desa yang memiliki kompetensi yang baik.

\section{Saran}

Berdasarkan kesimpulan di atas, maka peneliti memberikan rekomendasi pada impelementasi Aplikasi SISKEUDES 2.0 sebagai berikut meningkatkan sarana dan prasarana desa penunjang aplikasi SISKEUDES dengan memanfaatkan APBDes, meningkatkan kualitas sumberdaya manusia yang memiliki skil dibidang 
teknologi dan informasi, pemerintah daerah atau provinsi melalui Dinas Pemebrdayaan Masyarakat dan Desa dapat mengevaluasi teknik pelatihan atau workshop yang selma ini dianggap belum efektif bagi aparatur desa, pemerintah pusat dapat membuat kebijakan rekrutmen aparatur desa secara terbuka dengan menggunakan atau mengabungkan aparatur desa dengan Pegawai Pemerintah dengan Perjanjian Kerja (PPPK) supaya aparatur desa dapat lebih berkualitas.

\section{DAFTAR PUSTAKA}

Creswell, J. W. (2014). Research Design (Pendekatan Kualitatif, Kuantitatif, dan Mixed). Yogyakarta: Pustaka Pelajar.

Damanik, M. P., \& Purwaningsih, E. H. (2017). E-GOVERNMENT DAN APLIKASINYA DI LINGKUNGAN PEMERINTAH DAERAH ( STUDI KASUS KUALITAS INFORMASI WEBSITE KABUPATEN BENGKALIS PROPINSI RIAU ). Jurnal Studi Komunikasi Dan Media, 21(2), 151164.

https://doi.org/10.31445/jskm.20 17.210202

Endang, \& Hayati, R. (2020). IMPLEMENTASI APLIKASI SISTEM KEUANGAN DESA (SISKEUDES) DILIHAT DARI ASPEK SUMBER DAYA DI DESA BENTOT KECAMATAN PATANGKEP TUTUI KABUPATEN BARTIM. JAPB, 3(2), 893-903.

Firdausy, C. M., Suryana, A., Nugroho, R., \& Suhartoko, Y. B. (2019). Prosiding Seminar Nasional Bagian I Pusat Penelitian Badan Keahlian DPR RI. In REVOLUSI INDUSTRI 4.0 DAN PEMBANGUNAN EKONOMI BERKELANJUTAN (pp. 1-222).

Harmiati, H., Mulyadi, M., Suri, E. W., \&
Triyanto, D. (2019). ANALISIS PEMBERIAN DANA DESA DALAM PENURUNAN ANGKA KEMISKINAN DI PROVINSI BENGKULU. Mimbar: Jurnal Penelitian Sosial Dan Politik, $8(1)$, 23-30. https://doi.org/https://doi.org/10. 32663/jpsp.v8i1.833

Harmiati, Alexsander, Triyanto, D., Maya, M., \& Riastuti, F. (2020). ANALISIS PEMETAAN COLLABORATIVE GOVERNANCE DALAM PROGRAM KELUARGA BERENCANA DI KOTA BENGKULU. Mimbar: Jurnal Penelitian Sosial Dan Politik, 9(1). https://doi.org/https://doi.org/10. 32663/jpsp.v9i1

Jamaluddin, Y., Sumaryana, A., Rusli, B., \& Buchari, R. A. (2018). Analisis Dampak Pengelolaan dan Penggunaan Dana Desa terhadap Pembangunan Daerah Analysis of the Impact of Management and Use of Village Funds on Regional Development, 6(1), 14-24.

Kurnia, E. T. (2019). ANALISIS PERSEPSI APARATUR DESA TERHADAP PENERIMAAN DAN PENGGUNAAN APLIKASI SISTEM KEUANGAN DESA (SISKEUDES) (Studi Kasus di Kabupaten Ketapang).

Malahika, J. M., Karamoy, H., \& Pusung, R. J. (2018). PENERAPAN SISTEM KEUANGAN DESA (SISKEUDES) PADA ORGANISASI PEMERINTAHAN DESA (STUDI KASUS DI DESA SUWAAN KECAMATAN KALAWAT KABUPATEN MINAHASA UTARA). Juranl Riset Akuntansi Goung Concer, 13(4), 578-583.

Muhadjir, N. (2012). Metode Penelitian Kualitatif Edisi IV. Indonesia: Rake Sarasin.

Munti, F. (2017). Determinan Kinerja Pengelolaan Keuangan Desa: Studi pada Kecamatan Gandapura Kabupaten Bireuen Aceh. Jurnal 
Vol.2 No.2 Desember 2020

Akuntansi Dan Investasi, 18(2), 172-182.

https://doi.org/10.18196/jai.1802

81

Pratiwi, D. N., \& Pravasanti, Y. A. (2020). Analisis Penggunaan Siskeudes dalam Pengelolaan Dana Desa. Jurnal Akuntansi Dan Pajak, 20(2), 217-223.

Puspasari, O. R., \& Purnama, D. (2018). Implementasi sistem keuangan desa dan kualitas laporan keuangan pemerintah desa di kabupaten kuningan. JUrnal Kajian Akuntansi, 2(2), 145-159.

Ridwan, M. A. (2019). ANALISIS PERAN APLIKASI SISTEM KEUANGAN DESA ( SISKEUDES ) DALAM MENINGKATKAN KUALITAS AKUNTABILITAS KEUANGAN DESA DITINJAU DARI PERSPEKTIF EKONOMI ISLAM.

Triyanto, D. (2018). Analisis Kinerja Pendamping Desa Dalam Upaya Membangun Kemandirian Desa. Mimbar: Jurnal Penelitian Sosial Dan Politik, 7(2), 56-62. https://doi.org/https://doi.org/10. 32663/jpsp.v7i2.669

Triyanto, D., \& Efendi, S. (2019). Analisis Penerapan Elektronik Kesehatan ( E-Kes) di Puskesmas Rawat Inap Kota Bengkulu. Jurnal Administrasi Publik: Public Admnistration Journal, 9(2), 158-165. https://doi.org/http://dx.doi.org/1 0.31289/jap.v9i2.2901

Yuningsih, R. (2016). PEMERINTAH DAERAH KABUPATEN TOLITOLI DI KOTA PALU. Jurnal Katalogis, 4(8), 175-183. 